\title{
SATISFACTION WITH SERVICES IN HOMESTAY BUSINESS: THE CASE OF RANONG PROVINCE, THAILAND
}

\author{
Boonthai Keawkunti \\ Supathra Panee
}

Suan Sunandha Rajabhat University, Bangkok, Thailand

This research studies the satisfaction with the homestay services on the example Rayong province. Population of this research consists of tourists, questionnaires were collected randomly from 400 people. Data analysis and processing have been applied using the statistical packages, inter alia, this research operates such notions as percentage, average and standard deviation. After data analysis we have found that: 1) the majority of tourists in our group are male, between 31 and 40 y.o., with a bachelor's degree, managing own business, with income over 30,000 Baht, intending to come to homestay again in the period of nearest 6-12-months; 2) majority of tourists in our group travel on average about 1-2 times a year, selecting a homestay in a city, the key reason for this choice being to save around 1,000-2,000 Baht per person per night. From a homestay venue, the tourists usually need such services as computer, Internet and taking them to sightseeing sites. In the second part of our research we also measured satisfaction with the homestay services using several sets of the related variables.

Keywords: satisfaction with service; homestay business; tourists; Ranong province; Thailand.

\section{Introduction}

Homestay is a highly specific type of tourism focused cultural exchange during a tourist visit. This exchange takes place between a guest and a home owner, also called a homestay entrepreneur. Most of homestay entrepreneurs worldwide have their own main career path, and for them homestay is just a supplement, a way to get extra income for their families, and also to contribute to the local community's development and popularization at the same time. In Thailand, for example, homestay business helps disseminate information on Thai culture in its various forms among foreigners.

Even though homestay business, as of today, does not create much income, as compared to other forms of tourism, this subsector is growing continuously because it is still a business which has its own sale point and it also based on unique cultural identity.

According to the information provided by the Department of Tourism, Ministry of Tourism in Thailand, currently, there are more than 1,000 homestays in the country.

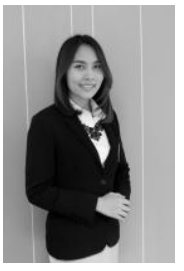

Boonthai Keawkunti

$\mathrm{PhD}$, lecturer in College of innovation and management, Suan Sunandha Rajabhat University, Bangkok, Thailand

Research interests are concentrated around marketing, consumers behavior, customers satisfaction evaluation and measurement, Thailand tourism market

E-mail: boonthai.ke@ssru.ac.th 
Department of Tourism promotes the related government's policy of homestay business development because this type of activity creates value the whole society and is also the source of added value to national economy. Homestay business manages to support unique national lifestyle, culture and local wisdom, and at the same time it also creates extra jobs, products and services. Thus, it provokes the locals to be more creative and thus to bring income to the community.

Rayong province has quite high potential for tourism development, first of all, due to its natural environment and lifestyle, culture and traditions. Therefore, many communities in Rayong province, on the village level already, organize homestay businesses in order to welcome tourists, so that the latter can not only stay, but can also live like truly local people, learn the local lifestyle, engage in various activities, like ecotourism, other cultural or adventurous travel activities.

Travelling as such often involves rural culture, so when tourists are learning something new, get acquainted with the local lifestyle, courtesy, and kindness of people in Rayong province, their centuries old culture and traditions - this also can be considered as a type of tourism services. Moreover, this is a truly most unique type of services since it combines travelling with various other tourism activities, all within natural environment.

For all these reasons, we have been very much interested to study the satisfaction with all the services related to homestay in Rayong province, mostly because this sort of information can further serve as the guidance for raising the service quality of homestay business in Rayong province so that it can be more able to meet customer demand effectively.

\section{Methodology}

This research has been based on a survey. General population of this study covers all the tourists who used homestay services in Rayong province, and at the time of data preparation their number was 789,666 people. Thus, we have used the Taro Yamane's formula (Taro Yamane, 1970) at the significant level of 0.05, and found that we would need 400 samples for our random sampling method. The independent variables of this research include: gender, age, education level, income per month and the intention to come back to this or nearby homestay again. And the dependent variable is satisfaction with services of a homestay business in Rayong province. 7 components were measured in this regard, including: specific features of a homestay and meeting room in homestay style, service charges, service channel and marketing promotion, other processes related to management, service provider, and environment management.

Since we have decided to carry out a survey, questionnaire became our key tool. It was divided into two stages as follows:

Stage 1. General data was collected first, such as gender, age, education level, career, income per month and intending to come back to homestay again. Checklist was offered for this to each participant.

Stage 2. Satisfaction with the services provided by a particular homestay business in Rayong province was measured. This part of the survey contained 49 questions, and each respondent was asked to measure certain aspect of satisfaction with a service using Likert's scale with 5 levels. 


\section{SATISFACTION WITH THE SERVICES OF}

Inspection tools were first applied in relation to the research questions and structure so that to check the content validity. 3 professionals were invited for that, and then also a theater group of 30 people tested our instrument. The confirmation result was as high as .9807 .

Statistical package was then used for data analysis, namely, descriptive statistics, including such features as Frequency and Percentage, and also Mean and Standard Deviation.

\section{Results}

Most tourists in our randomly selected group turned out to be male, in the age between 31 and 40, who graduated with Bachelor's degree, most of them had businessed of their own, and monthly income over 30,000 Baht, intending to come back to a homestay again in the nearest 6-12 months (see Table 1 for more details).

Table 1. General data on our randomly selected sample group (coauthors' data)

\begin{tabular}{|c|c|c|}
\hline General data & Amount & Percentage \\
\hline \multicolumn{3}{|l|}{ Gender } \\
\hline Male & 205 & 51.2 \\
\hline Female & 195 & 48.8 \\
\hline \multicolumn{3}{|l|}{ Age } \\
\hline Less then 30 years & 45 & 11.2 \\
\hline $31-40$ years & 130 & 32.5 \\
\hline $41-50$ years & 95 & 23.8 \\
\hline Over 50 years & 130 & 32.5 \\
\hline \multicolumn{3}{|l|}{ Education Level } \\
\hline Primary School & 0 & 0 \\
\hline High School & 18 & 4.5 \\
\hline High School/ Vocational Certificate & 99 & 24.8 \\
\hline Bachelor's Degree & 165 & 41.3 \\
\hline Higher than Bachelor's Degree & 118 & 29.5 \\
\hline \multicolumn{3}{|l|}{ Career } \\
\hline Governance Officer/State Enterprise & 112 & 28 \\
\hline Employee & 86 & 21.5 \\
\hline Student /undergraduate & 30 & 7.5 \\
\hline Owner business & 170 & 42.5 \\
\hline Other (please, specify) & 2 & 0.5 \\
\hline
\end{tabular}

\begin{tabular}{lcc}
\hline General data & Amount & Percentage \\
\hline Income per month & 2 & \\
Less than 5,000 Baht & 32 & 0.5 \\
5,001-10,000 Baht & 71 & 8 \\
$10,001-15,000$ Baht & 144 & 36 \\
$15,000-20,000$ Baht & 151 & 37.8 \\
More than 30,000 Baht & \\
\hline
\end{tabular}




\begin{tabular}{lcc}
\hline General data & Amount & Percentage \\
\hline Intention to come back to homestay again & & \\
Will not come back again & 0 & 0 \\
Coming back again in 3 months & 43 &
\end{tabular}




\section{SATISFACTION WITH THE SERVICES OF}

\begin{tabular}{lcc}
\hline Travelling behavior and Stay & Amount & Percentage \\
\hline What is the reason why this time you have chosen & & \\
homestay (for this, more than one answer was allowed) & & \\
Close enough to a particular landmark & 371 & 18.7 \\
Many activities around & 330 & 16.6 \\
Low price & 374 & 18.8 \\
Like it because it is natural and calm & 305 & 15.4 \\
Homestay owner is courteous & 315 & 15.9 \\
Style/ Reliability of place & 285 & 14.4 \\
Other & 6 & 0.3 \\
\hline How much the cost for your check-in at homestay? & & \\
More than 5,000 Baht/person/night & 10 & 2.5 \\
2001 - 5000 Baht/person/night & 128 & 32 \\
1001 - 2000 Baht/person/night & 240 & 60 \\
Less than 1000 Baht/person/night & 22 & 5.5 \\
\hline What services would you like to receive from homestay? & & \\
(More than 1 answer was allowed) & & \\
Computer / Internet connection & 394 & 17 \\
Singing karaoke & 294 & 12.7 \\
Food and beverages & 362 & 15.6 \\
Souvenir shop & 296 & 12.8 \\
Thai massage & 301 & 13 \\
Spa/Herbal steam bath & 315 & 13.6 \\
Laundry services & 343 & 14.8 \\
Other & 14 & 0.6 \\
\hline What activities did you use and you generally want from & & \\
a homestay? (More than 1 answer was allowed) & 352 & 16.7 \\
Boating/Cruise sightseeing & 281 & 13.4 \\
Fire show & 251 & 11.9 \\
Hiking & 269 & 12.8 \\
Environment-related activities & 205 & 9.8 \\
Religious sctivities & 318 & 15.1 \\
Observation and participation in house duties & 358 \\
Visit to an archaeological site & 68 & 17 \\
Other & 3.2 \\
\hline
\end{tabular}

Satisfaction with homestay services in Rayong province concerns, first of all, the features of rooms and interior of a homestay facility overall $(\bar{x}=3.90$, S.D. $=0.65)$ and all 8 variables in this category demonstrate high level of assessment: first goes the variable of size of the room provided for a stay $(\bar{x}=4.44$, S.D. $=0.72)$, then goes the variable of facilities' sufficiency $(\bar{x}=4.35$, S.D. $=0.73)$ and then - design and decor of both interior and exterior in a homestay $(\bar{x}=3.87$, S.D. $=0.64)$, finally, cleanliness of the toilet was assessed $(\bar{x}=$ 3.62, S.D. $=0.65)($ Table 3$)$. 
Table 3. Average value and standard deviation of satisfaction with the services provided by homestays in Rayong province

(coauthors' data)

\begin{tabular}{|c|c|c|c|c|c|c|c|c|}
\hline \multirow{3}{*}{$\begin{array}{l}\text { Features of accommodation and } \\
\text { homestay's style }\end{array}$} & \multicolumn{8}{|c|}{ Satisfaction Level } \\
\hline & \multicolumn{5}{|c|}{ Percentage } & \multirow[b]{2}{*}{$\bar{x}$} & \multirow[b]{2}{*}{ S.D. } & \multirow[b]{2}{*}{ Resul } \\
\hline & $\begin{array}{l}\text { Very } \\
\text { High }\end{array}$ & High & Middle & Low & $\begin{array}{l}\text { Very } \\
\text { Low }\end{array}$ & & & \\
\hline $\begin{array}{l}\text { 1. Size of the room and its overall } \\
\text { adequacy to your demands }\end{array}$ & 0.0 & 0.0 & 13.5 & 29.0 & 57.5 & 4.44 & 0.72 & High \\
\hline 2. Sufficiency of facilities & 0.0 & 0.0 & 15.0 & 35.0 & 50.0 & 4.35 & 0.73 & High \\
\hline $\begin{array}{l}\text { 3. Design and decor of both interior } \\
\text { and exterior of a homestay }\end{array}$ & 0.0 & 0.5 & 26.5 & 58.7 & 14.3 & 3.87 & 0.64 & High \\
\hline $\begin{array}{l}\text { 4. How well is the local identity } \\
\text { reflected in this place }\end{array}$ & 0.0 & 1.0 & 36.0 & 53.5 & 9.5 & 3.72 & 0.64 & High \\
\hline 5. Cleanliness of your room & 0.0 & 1.0 & 28.7 & 63.3 & 7.0 & 3.76 & 0.58 & High \\
\hline 6. Cleanliness of the toilet & 0.0 & 1.0 & 44.5 & 46.0 & 8.5 & 3.62 & 0.65 & High \\
\hline $\begin{array}{l}\text { 7. Facilities provided, such as } \\
\text { electrical equipment, furniture etc. }\end{array}$ & 0.0 & 0.5 & 35.2 & 55.8 & 8.5 & 3.72 & 0.62 & High \\
\hline $\begin{array}{l}\text { 8. Supplementary services, including } \\
\text { running water }\end{array}$ & 0.0 & 0.0 & 39.5 & 49.2 & 11.3 & 3.72 & 0.65 & High \\
\hline Total & & & & & & 3.90 & 0.65 & High \\
\hline
\end{tabular}

Satisfaction with the price level of the homestay service in Rayong province in general showed the following results: $\bar{x}=3.84$, S.D. $=0.66$. Thus, all 4 variables of this dimension demonstrated quite high level of satisfaction, however, the top priority rank got the room rate $(\bar{x}=3.88$, S.D. $=0.57)$, then goes the service and beverages' fee $(\bar{x}=3.87$, S.D. $=0.66)$, and then the fees for other operations and activities $(\bar{x}=3.83$, S.D. $=0.70)$. The last one is the supplement fee for car or boat transportation $(\bar{x}=3.76$, S.D. $=0.72$ ) (see more details in Table 4).

Table 4. Average value and standard deviation of satisfaction with services' charges (coauthors' data)

\begin{tabular}{|c|c|c|c|c|c|c|c|c|}
\hline \multirow{3}{*}{ Services } & \multicolumn{8}{|c|}{ Satisfaction Level } \\
\hline & \multicolumn{5}{|c|}{ Percentage } & \multirow[b]{2}{*}{$\bar{x}$} & \multirow[b]{2}{*}{ S.D. } & \multirow[b]{2}{*}{ Result } \\
\hline & $\begin{array}{l}\text { Very } \\
\text { High }\end{array}$ & High & Middle & Low & $\begin{array}{l}\text { Very } \\
\text { Low }\end{array}$ & & & \\
\hline 1. Room rates & 0.0 & 0.0 & 23.0 & 66.2 & 10.8 & 3.88 & 0.57 & High \\
\hline 2. Service and beverage fee & 0.0 & 0.0 & 29.0 & 54.7 & 16.3 & 3.87 & 0.66 & High \\
\hline $\begin{array}{l}\text { 3. Supplement services such as car/ } \\
\text { boat transportation }\end{array}$ & 0.0 & 0.0 & 41.0 & 42.2 & 16.8 & 3.76 & 0.72 & High \\
\hline $\begin{array}{l}\text { 4. Service charges for other } \\
\text { operations and/or activities }\end{array}$ & 0.0 & 0.0 & 36.5 & 48.5 & 17.0 & 3.83 & 0.70 & High \\
\hline \multicolumn{6}{|c|}{ Total } & 3.84 & 0.66 & High \\
\hline
\end{tabular}

Satisfaction with channels of information concerning the homestay services in Rayong province got the following overall result: $\bar{x}=3.84$, S.D. $=0.63$. Thus, all 5 variables of this group were at high level of satisfaction assessment. The highest grade got the travelling information through government agencies $(\bar{x}=3.98$, S.D. $=0.59)$, then goes advance 
booking and registration information $(\bar{x}=3.95$, S.D. $=0.48)$ and then - signs or activities in the area $(\bar{x}=3.80$, S.D. $=0.69)$. Finally, creating a travel service network in the local communities got the lowest, though still high result: $\bar{x}=3.71$, S.D. $=0.69$ (more details - in Table 5).

Table 5. Average value and standard deviation of satisfaction with the information channel on homestay services

(coauthors' data)

\begin{tabular}{|c|c|c|c|c|c|c|c|c|}
\hline \multirow{3}{*}{ Service Channel } & \multicolumn{8}{|c|}{ Satisfaction Level } \\
\hline & \multicolumn{5}{|c|}{ Percentage } & \multirow[b]{2}{*}{$\overline{\mathrm{x}}$} & \multirow[b]{2}{*}{ S.D. } & \multirow[b]{2}{*}{ Result } \\
\hline & $\begin{array}{l}\text { Very } \\
\text { High }\end{array}$ & High & Middle & Low & $\begin{array}{l}\text { Very } \\
\text { Low }\end{array}$ & & & \\
\hline 1. Advance booking and registration & 0.0 & 0.0 & 14.0 & 77.0 & 9.0 & 3.95 & 0.48 & High \\
\hline $\begin{array}{l}\text { 2. Travelling information provided by } \\
\text { government agencies }\end{array}$ & 0.0 & 0.0 & 18.5 & 65.5 & 16.0 & 3.98 & 0.59 & High \\
\hline $\begin{array}{l}\text { 3. Creating a travel service network in } \\
\text { a community }\end{array}$ & 0.0 & 0.0 & 42.7 & 44.0 & 13.3 & 3.71 & 0.69 & High \\
\hline $\begin{array}{l}\text { 4. Signs on how to reach } \\
\text { accommodation }\end{array}$ & 0.0 & 0.0 & 39.5 & 45.2 & 15.3 & 3.76 & 0.70 & High \\
\hline $\begin{array}{l}\text { 5. Other activities and directions in } \\
\text { the area }\end{array}$ & 0.0 & 0.0 & 35.7 & 48.5 & 15.8 & 3.80 & 0.69 & High \\
\hline \multicolumn{6}{|c|}{ Total } & 3.84 & 0.63 & High \\
\hline
\end{tabular}

Table 6. Average value and standard deviation of satisfaction with marketing promotion of homestays

(coauthors' data)

\begin{tabular}{|c|c|c|c|c|c|c|c|c|}
\hline \multirow{3}{*}{ Marketing Promotion Means } & \multicolumn{8}{|c|}{ Satisfaction Level } \\
\hline & \multicolumn{5}{|c|}{ Percentage } & \multirow[b]{2}{*}{$\overline{\mathrm{x}}$} & \multirow[b]{2}{*}{ S.D. } & \multirow[b]{2}{*}{ Result } \\
\hline & $\begin{array}{l}\text { Very } \\
\text { High }\end{array}$ & High & Middle & Low & $\begin{array}{l}\text { Very } \\
\text { Low }\end{array}$ & & & \\
\hline 1. Advertising through brochures & 0.0 & 0.0 & 17.5 & 71.0 & 11.5 & 3.94 & 0.54 & High \\
\hline 2. Advertising online & 0.0 & 0.0 & 24.3 & 64.7 & 11.0 & 3.87 & 0.58 & High \\
\hline 3. Word of mouth about the service & 0.0 & 0.0 & 42.3 & 42.2 & 15.5 & 3.73 & 0.71 & High \\
\hline 4. Labeling of signs & 0.0 & 0.0 & 63.3 & 46.4 & 17.3 & 3.81 & 0.71 & High \\
\hline $\begin{array}{l}\text { 5. PR activities by the Travel \& Tourism } \\
\text { Authority Network Agencies of the } \\
\text { Department of Local Administration }\end{array}$ & 0.0 & 0.0 & 25.0 & 61.5 & 13.5 & 3.89 & 0.61 & High \\
\hline $\begin{array}{l}\text { 6. Special discounts for the returning } \\
\text { customers }\end{array}$ & 0.0 & 0.0 & 35.0 & 49.0 & 16.0 & 3.81 & 0.69 & High \\
\hline $\begin{array}{l}\text { 7. Promotion prices during the festival } \\
\text { season or low season }\end{array}$ & 0.0 & 0.0 & 38.5 & 46.8 & 14.7 & 3.76 & 0.69 & High \\
\hline \multicolumn{6}{|l|}{\begin{tabular}{|c|c|c|} 
& Totals
\end{tabular}} & 3.83 & 0.65 & High \\
\hline
\end{tabular}

Satisfaction with marketing promotion of homestay businesses in Rayong province has been measured with application of 7 variables, all of them scoring at high level. The best result got advertising via brochures $(\bar{x}=3.94$, S.D. $=0.54)$, then goes advertising as PR actions taken by the Travel \& Tourism Authority Network Agencies of the Department of Local Administration $(\bar{x}=3.89$, S.D. $=0.61)$, the third in rank is online advertising with $\bar{x}=$ 
3.87, S.D. $=0.58$. The lowest result got the word of mouth $(\bar{x}=3.73$, S.D. $=0.71)$ (more details in Table 6 above).

Satisfaction with management processes in homestay businesses in Rayong province demonstated the following result: ${ }^{\bar{x}}=3.90$, S.D. $=0.82$, and all 9 variables of this category were at quite high level. Firstly goes the security of a homestay $(\bar{x}=4.28$, S.D. $=0.67)$. Second was readiness of the first-aid toolkit ( $\bar{x}=4.08$, S.D. $=0.76$ ), while the third in rank was lighting $(\bar{x}=3.91$, S.D. $=0.61)$. The lowest results, unfortunately, got such parameters as food and cleanliness $(\bar{x}=3.80$, S.D. $=0.56)$. More details are presented in Table 7 .

Table 7. Average values and standard deviation for the process management aspects (coauthors' data)

\begin{tabular}{|c|c|c|c|c|c|c|c|c|}
\hline \multirow{3}{*}{ Processes } & \multicolumn{8}{|c|}{ Satisfaction Level } \\
\hline & \multicolumn{5}{|c|}{ Percentage } & \multirow[b]{2}{*}{$\bar{x}$} & \multirow[b]{2}{*}{ S.D. } & \multirow[b]{2}{*}{ Result } \\
\hline & Very High & High & Middle & Low & $\begin{array}{l}\text { Very } \\
\text { Low }\end{array}$ & & & \\
\hline $\begin{array}{l}\text { 1. Security of a } \\
\text { homestay }\end{array}$ & 0.0 & 0.0 & 23.0 & 41.0 & 36.0 & 4.28 & 0.67 & High \\
\hline $\begin{array}{l}\text { 2. Availability of the } \\
\text { first-aid toolkit }\end{array}$ & 0.0 & 0.0 & 25.0 & 42.5 & 32.5 & 4.08 & 0.76 & High \\
\hline $\begin{array}{l}\text { 3. Cleanness of food } \\
\text { preparation and } \\
\text { hygiene in the kitchen }\end{array}$ & 0.0 & 0.0 & 31.0 & 55.5 & 13.5 & 3.83 & 0.64 & High \\
\hline $\begin{array}{l}\text { 4. Food is clean, tastes } \\
\text { good and is provided } \\
\text { in a reasonable } \\
\text { quantity }\end{array}$ & 0.0 & 0.0 & 27.8 & 64.7 & 7.5 & 3.80 & 0.56 & High \\
\hline $\begin{array}{l}\text { 5. Service is unique } \\
\text { and reveals the local } \\
\text { identity }\end{array}$ & 0.0 & 0.5 & 37.8 & 49.2 & 12.5 & 3.74 & 0.67 & High \\
\hline 6. Lighting & 0.0 & 0.0 & 23.5 & 62.0 & 14.5 & 3.91 & 0.61 & High \\
\hline $\begin{array}{l}\text { 7. Bedding supplies } \\
\text { are adequate and clean }\end{array}$ & 0.0 & 0.0 & 27.5 & 59.5 & 13.0 & 3.86 & 0.62 & High \\
\hline $\begin{array}{l}\text { 8. Vehicle to access } \\
\text { the homestay }\end{array}$ & 0.0 & 0.0 & 34.2 & 50.5 & 15.3 & 3.81 & 0.68 & High \\
\hline $\begin{array}{l}\text { 9. Place and equipment } \\
\text { for training/ seminar } \\
\text { (when applicable) }\end{array}$ & 0.0 & 0.0 & 33.5 & 52.0 & 14.5 & 3.81 & 0.67 & High \\
\hline & & tal & & & & 3.90 & 0.82 & High \\
\hline
\end{tabular}

Satisfaction with servicing at a homestay demonstrtated the following result: $\bar{x}=3.89$, S.D. $=0.66$. And again, all 9 variables separately demonstrated quite high results. The highest rank got good manners and gentle style $(\bar{x}=3.96$, S.D. $=0.64)$. Second goes understanding tourists' demands $(\bar{x}=3.96$, S.D. $=0.70)$ and then, being friendly overll $(\bar{x}=$ 3.95 , S.D. $=0.68)$. The lowest rank got providing suggestions and assistantance $(\bar{x}=3.79$, S.D. $=0.68)$. More details - in Table 8 below. 


\section{SATISFACTION WITH THE SERVICES OF}

Table 8. Average values and standard deviation for various aspects of servicing in a homestay (coauthors' data)

\begin{tabular}{|c|c|c|c|c|c|c|c|c|}
\hline \multirow{3}{*}{ Services } & \multicolumn{8}{|c|}{ Satisfaction Level } \\
\hline & \multicolumn{5}{|c|}{ Percentage } & \multirow{2}{*}{$\bar{x}$} & \multirow{2}{*}{ S.D. } & \multirow{2}{*}{ Resul } \\
\hline & $\begin{array}{l}\text { Very } \\
\text { High }\end{array}$ & High & Middle & Low & $\begin{array}{l}\text { Very } \\
\text { Low }\end{array}$ & & & \\
\hline 1. Warming welcome & 0.0 & 0.0 & 17.0 & 73.0 & 10.0 & 3.93 & 0.52 & High \\
\hline $\begin{array}{l}\text { 2. Good manners and } \\
\text { gentle style }\end{array}$ & 0.0 & 0.0 & 22.5 & 59.0 & 18.5 & 3.96 & 0.64 & High \\
\hline $\begin{array}{l}\text { 3. Looking clean and } \\
\text { accurate }\end{array}$ & 0.0 & 0.0 & 30.0 & 49.2 & 20.8 & 3.91 & 0.71 & High \\
\hline $\begin{array}{l}\text { 4. Understanding tourists' } \\
\text { demands }\end{array}$ & 0.0 & 0.0 & 26.5 & 51.0 & 22.5 & 3.96 & 0.70 & High \\
\hline 5. Friendly staff & 0.0 & 0.5 & 23.8 & 55.7 & 20.0 & 3.95 & 0.68 & High \\
\hline $\begin{array}{l}\text { 6. Suggestions and } \\
\text { assistance }\end{array}$ & 0.0 & 0.0 & 35.8 & 49.7 & 14.5 & 3.79 & 0.68 & High \\
\hline 7. Communication skills & 0.0 & 0.0 & 29.0 & 57.5 & 13.5 & 3.85 & 0.63 & High \\
\hline 8. Speed of servicing & 0.0 & 0.0 & 32.3 & 50.0 & 17.7 & 3.86 & 0.69 & High \\
\hline $\begin{array}{l}\text { 9. Accuracy and prudence } \\
\text { in servicing }\end{array}$ & 0.0 & 0.0 & 33.5 & 50.3 & 16.2 & 3.83 & 0.68 & High \\
\hline \multicolumn{6}{|c|}{ Total } & 3.89 & 0.66 & High \\
\hline
\end{tabular}

Table 9. Average value and standard deviation for the environment management parameters (coauthors' data)

\begin{tabular}{|c|c|c|c|c|c|c|c|c|}
\hline \multirow{3}{*}{ Environment Management } & \multicolumn{8}{|c|}{ Satisfaction Level } \\
\hline & \multicolumn{5}{|c|}{ Percentage } & \multirow[b]{2}{*}{$\bar{x}$} & \multirow[b]{2}{*}{ S.D. } & \multirow[b]{2}{*}{ Result } \\
\hline & $\begin{array}{l}\text { Very } \\
\text { High }\end{array}$ & High & Middle & Low & $\begin{array}{l}\text { Very } \\
\text { Low }\end{array}$ & & & \\
\hline $\begin{array}{l}1 . \quad \text { Air and lighting } \\
\text { appropriately }\end{array}$ & 0.0 & 0.0 & 17.5 & 71.8 & 10.8 & 3.93 & 0.53 & High \\
\hline $\begin{array}{l}\text { Inside environment and } \\
\text { clean surroundings }\end{array}$ & 0.0 & 0.0 & 25.0 & 57.3 & 17.8 & 3.93 & 0.65 & High \\
\hline 3. View from the room & 0.0 & 0.0 & 34.5 & 51.8 & 13.8 & 3.79 & 0.66 & High \\
\hline $\begin{array}{l}\text { 4. Car park area or parking } \\
\text { space }\end{array}$ & 0.0 & 0.0 & 39.3 & 51.7 & 9.0 & 3.70 & 0.63 & High \\
\hline $\begin{array}{l}\text { 5. Having some shady space } \\
\text { with trees and flowers }\end{array}$ & 0.0 & 0.0 & 31.0 & 57.0 & 12.0 & 3.81 & 0.63 & High \\
\hline 6. Natural food & 0.0 & 0.0 & 31.0 & 52.0 & 17.0 & 3.86 & 0.68 & High \\
\hline $\begin{array}{l}\text { 7. Availability of a waste } \\
\text { disposal system and sewage }\end{array}$ & 0.0 & 0.0 & 34.8 & 50.0 & 15.2 & 3.81 & 0.68 & High \\
\hline \multicolumn{6}{|l|}{ T } & 3.83 & 0.64 & High \\
\hline
\end{tabular}

Satisfaction with the environment in and around the homestay overall got the following result: $\bar{x}=3.83$, S.D. $=0.64$, and all 7 variables scored quite high levels. Firstly goes air and lighting, with $\bar{x}=3.93$, S.D. $=0.53$. Then follows the variable of the inside environment and clean surroundings $(\bar{x}=3.93$, S.D. $=0.65)$, then - natural food, free from additives $(\bar{x}=3.86$, S.D. $=0.68)$ respectively. The lowest score got the factor of car park area or parking space availability $(\bar{x}=3.70$, S.D. $=0.63)$ (for more details see Table 9 above). 


\section{Acknowledgement}

The author would like to thank the Research and Development Institute, Suan Sunandha Rajabhat University, Bangkok, Thailand for the financial support of this research.

\section{References}

Pranee, S. (2016). Expectaion and satisfaction with service quality of public bus, taxi of taxi cooperative in Bangkok. The 5th National Science and Technology Conference B.E. 2559. Sustainable development research, 1- 2 December, 2016, Bangkok.

Sayanon, A., \& Sompopsakul, P. (2010). Sustainable Tourism Value Creation of Homestay Business: Case study of the homestay at Ampawa flooding market, Samutsongkarm province. Thesis. Bangkok, Thailand: The University of The Thai Chamber of Commerce.

Seangpiroon, T., \& Nimnatipun, S. (2015). Satisfaction of Thai tourists with homestay service management in Sana district, Pranakornsirayutthaya province. Academic Presentation for the National Research Network, Graduate Study Conference.

Sontornsamai, W., \& Aimlekand, K. (2007). Study the service quality at homestay accommodation in East: Potential development to strength and sustainable of ecotourism and doing tourism business. Bangkok. National Research Council of Thailand.

Sutont, P. (2011). Travel behavior affecting the satisfaction with homestay business: Case study at Ampawa district, Samutsongkarm province. Pathumtani: Rajamangala University of Technology.

Wutsilpa, C., \& Pasunon, P. (2015). Expectation and satisfaction with using service at a homestay at Ampawa district, Samutsongkarm province. Thesis. Bangkok, Thailand: Faculty of Management Science.

Paper submitted

Paper accepted for publishing

Paper published online
21 December 2017

15 March 2018

30 March 2018 